\title{
Investigation on the performance of 'Fino' materials to stabilize expansive soil: A case study in Yeka Sub-City, Addis Ababa, Ethiopia
}

\author{
Tsion Mindaye ${ }^{1,}{ }^{*}$, Emer Tucay Quezon ${ }^{2}$ and Temesgen Ayna ${ }^{1}$ \\ ${ }^{1}$ Department of Civil Engineering, College of Engineering, Hawassa University, Hawassa, Ethiopia \\ ${ }^{2}$ Department of Civil Engineering, School of Civil \& Environmental Engineering, Institute of Technology, Ambo University \\ Hachalu Hundessa Campus, Ambo University, Ambo, Ethiopia
}

Global Journal of Engineering and Technology Advances, 2021, 06(02), 044-050

Publication history: Received on 08 January 2021; revised on 04 February 2021; accepted on 06 February 2021

Article DOI: https://doi.org/10.30574/gjeta.2021.6.2.0012

\begin{abstract}
Expansive soil swells when it is wet, and it will shrink when it dries. Due to this behavior of the soil, the strength and other properties of soil are inferior. To improve its properties, it is necessary to stabilize the soil with different stabilizers. Soil stabilization is a process to treat the soil to maintain, alter, or improve expansive soil performance. In this study, the potential of 'Fino' as stabilizing additive to expansive soil was investigated for the improving engineering properties of expansive soil to be used as subgrade material. The evaluation involved the determination of the Free Swell test, CBR test, Atterberg's limits, and the Proctor test of expansive soil in its natural state as well as when mixed with varying proportions of 'Fino.' The practices were performed on six proportions 5\%, 10\%, 15\%, 20\%, 25\% and 30 $\%$ with expansive soil. The research result indicated a considerable reduction in Swelling, and the Maximum dry Density of soil was improved. Optimum moisture content decreased in increasing 'Fino.' At 30\% of 'Fino,' the CBR values of expansive soil increased from $1.06 \%$ to $5.94 \%$, Liquid Limit decreased from $95.2 \%$ to $29.4 \%$, plasticity index decreased from $57.24 \%$ to $17.82 \%$ and the degree of expansion of the natural subgrade soil has reduced from "very high to medium." Hence, it is concluded that the 'Fino' at 30\% has shown significant improvement in the expansive soil's engineering properties meeting the ERA and AASHTO Standard specifications requirements for road subgrade material.
\end{abstract}

Keywords: Expansive Soil; Index Properties; 'Fino'; Subgrade Strength.

\section{Introduction}

All Civil Engineering structures are founded on the soil. The subgrade soil, an integral part of the road pavement, is usually stressed to an absolute minimum stress level due to the traffic loads. The subgrade soil should be of good quality. Expansive soil is a poor material to employ in road construction [1]. The engineering characteristics of expansive soil are mainly affected by the fluctuation of moisture content. Several issues addressed, such as the swelling and shrinking behavior of expansive soil, cause significant damage to pavement layers [2]. Therefore, identifying and treatment of poor subgrade soil is an essential objective. Replacement of the problematic soil by the selective material is one of the common solutions. However, it is very costly and impractical in highway projects due to the projects' huge volume. Generally, soil stabilization is concerned with increasing volume stability, strength, and durability [3]. Improvement of poor subgrade soils using lime, Portland cement, and other chemicals is also an effective solution; however, using these admixtures adds supplementary cost [4]. In recent years, utilizing industrial by-products in treating problematic soils is in high demand. It promotes more sustainable construction and decreases the cost [5]. 'Fino' is an industrial byproduct from aggregate crusher plants and quarry sites. Therefore, the employment of 'Fino' as an admixture to improve the properties of poor subgrade involves economic and environmental advantages.

\footnotetext{
${ }^{*}$ Corresponding author: Tsion Mindaye. E-mail: tsionmi2010@gmail.com

Department of Civil Engineering, College of Engineering, Hawassa University, Hawassa, Ethiopia. 


\section{Literature Review}

Expansive soils are clay soils with high plasticity. These soils are mostly found in arid and semiarid regions. Expansive soils form a major soil group in Ethiopia and occur in the high lands, mostly in the western, central, and southwestern parts of the country. In most cases, the dominant clay mineral component is montmorillonite [6]. Expansive soils undergo volumetric changes upon wetting and drying, thereby causing ground heave and settlement problems. This characteristic causes considerable damage to structures, particularly light buildings and pavements, if not adequately cared for [7]. In road construction, all the naturally available material cannot be utilized as a construction material. There are some problematic soils (such as expansive soils) and soils with limitations to meet specifications and design standards. The application of stabilizing agents can improve the problematic nature and limitations of such soils. There are various studies on the stabilization of Expansive soil. Additives are widely used for soil stabilization since they are cheaper than other stabilization methods. In recent years, there has been increasing use of industrial waste for this purpose. Some of these are, Stabilization of expansive soils using Rice Husk Ash [8]. Results show a slight improvement in the geotechnical properties of the expansive soil stabilized with RHA. Bagasse ash as a Subgrade Soil Stabilizing Material [9] shows the stabilization technique of using 15\% bagasse ash plus 3\% lime the native soil for use as a subgrade material is effective.

\section{Study Area, Materials, and Methods}

Expansive soils are found in some parts of the world. The Expansive soil sample used for this research work was collected from Yeka Sub City, Yeka Abado Condominium, it is located 16km east of Meskel Square, Addis Ababa, Ethiopia. Ethiopia is one of the countries known to have expansive soils. Most of Addis Ababa's city's subgrade material is heavy clay and silty-clay in nature, and a substantial area of the city subsoil is being occupied by black cotton soil. All tests conducted in the laboratory are based on ATSM standards [10]. The plasticity index (PI) of a different Addis Ababa city subgrade soil area is very high, ranging from 11.9 to $52.5 \%$, and high liquid limit (LL) ranging from 45.5 to $97.5 \%$. The soil's nature is highly expansive and from critical to highly critical [11]. The other material used in this research work is 'Fino.' 'Fino' is the waste of quarry sites and crusher plants in the process of producing standard aggregates used to concrete and asphalt pavement. The 'Fino' used for this research work was taken from Akaki Crusher Plant, Addis Ababa, Ethiopia. The mixed proportions of $0 \%, 5 \%, 10 \%, 15 \%, 20 \%, 25 \%$, and $30 \%$ of 'Fino' by weight with the sample expansive soil. The soil was air-dried, and different Sieves are used. The samples are tested in the laboratory like Specific gravity, Grain size analysis, Atterberg limits, Proctor test, CBR test, and Free swell test.

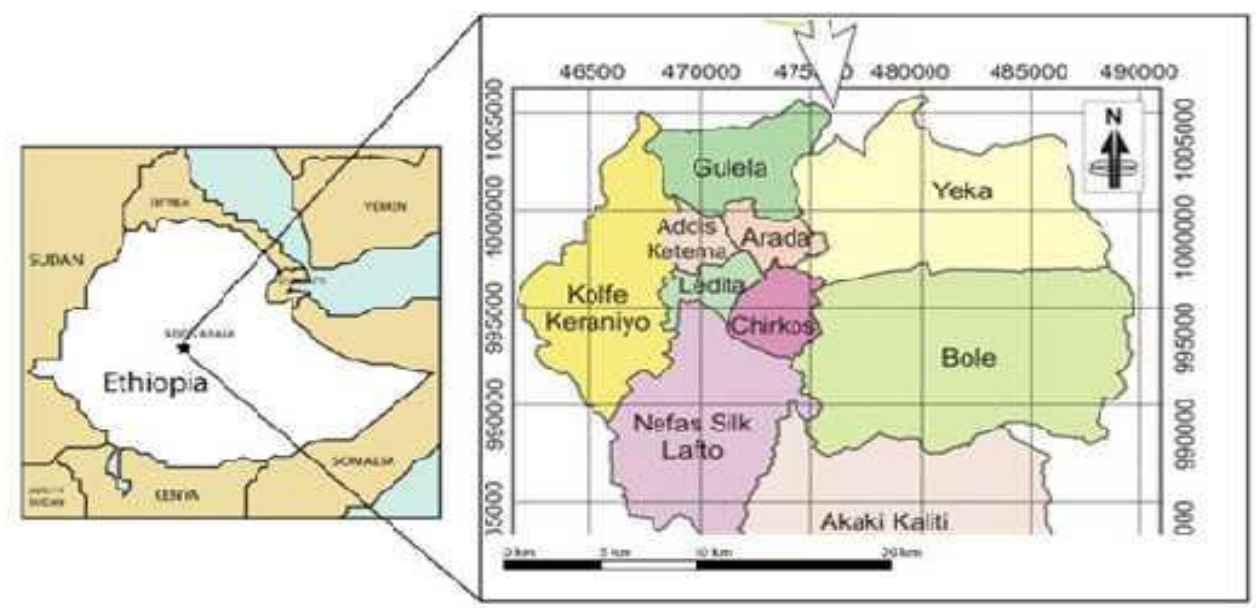

Figure 1 Map of the Study Area

\section{Results and Discussion}

In this research, the engineering properties and strength of the different mixed proportions of 'Fino' with expansive soil for subgrade were identified in laboratory tests. This identified laboratory result output was compared with the available international standards and parameters. Before blending, the natural subgrade soil and the 'Fino' were airdried, and the subgrade soil was pulverized and sieved on a $4.75 \mathrm{~mm}$ sieve. For Atterberg limit tests, soil sample passing sieve size $4.75 \mathrm{~mm}$ were again sieved on a sieve size of $0.425 \mathrm{~mm}$. Each specimen was prepared by addition of 'Fino' with a different percentage to have a sample with a predetermined percentage of stabilizer varying from $5 \%$ to $30 \%$ by 
weight of the soil sample and well mixed using a mixing spoon. After performing tests, the effect of 'Fino' on the engineering properties of expansive soil is presented as follows.

Table 1 Effect of 'Fino' on Atterberg's limit tests of soil

\begin{tabular}{|l|l|l|l|}
\hline \multirow{2}{*}{ 'Fino' (\% by weight) } & \multicolumn{3}{|l|}{ Atterberg's limit } \\
\cline { 2 - 4 } & LL value (\%) & PL value (\%) & PI value (\%) \\
\hline 0 & 95.2 & 37.96 & 57.24 \\
\hline 5 & 82.2 & 34.10 & 48.10 \\
\hline 10 & 73.20 & 28.37 & 44.83 \\
\hline 15 & 68.30 & 26.36 & 41.94 \\
\hline 20 & 57.30 & 24.37 & 32.93 \\
\hline 25 & 41.35 & 16.42 & 24.93 \\
\hline 30 & 29.40 & 11.58 & 17.82 \\
\hline
\end{tabular}

Table 2 Effects of 'Fino' on Free Swell of soil

\begin{tabular}{|l|l|l|}
\hline Content of 'Fino by weight.' & $\begin{array}{l}\text { Free Swell } \\
\text { Final Reading (ml) }\end{array}$ & Free Swell (\%) \\
\hline $0 \%$ & 25 & 150.00 \\
\hline $5 \%$ & 23.2 & 132.00 \\
\hline $10 \%$ & 22 & 120.00 \\
\hline $15 \%$ & 21.3 & 113.00 \\
\hline $20 \%$ & 20.9 & 109.00 \\
\hline $25 \%$ & 19.5 & 95.00 \\
\hline $30 \%$ & 18 & 80.00 \\
\hline
\end{tabular}

Table 3 Effect of 'Fino' on Moisture Density Relations of the Soil

\begin{tabular}{|l|l|l|l|l|l|l|l|}
\hline \% of 'Fino' & $\mathbf{0 \%}$ & $\mathbf{5 \%}$ & $\mathbf{1 0 \%}$ & $\mathbf{1 5 \%}$ & $\mathbf{2 0 \%}$ & $\mathbf{2 5 \%}$ & $\mathbf{3 0 \%}$ \\
\hline OMC (\%) & 36 & 30.97 & 28.50 & 26.70 & 26.00 & 25.80 & 25.30 \\
\hline MDD (g/cm3) & 1.25 & 1.27 & 1.31 & 1.34 & 1.38 & 1.42 & 1.46 \\
\hline
\end{tabular}

Table 4 Effect of 'Fino' on CBR- Swell of the soil

\begin{tabular}{|l|l|l|l|}
\hline \multirow{2}{*}{ Sample Proportions } & \multicolumn{3}{|l|}{$\begin{array}{l}\text { CBR- swell Values } \\
\text { at different number of blows }\end{array}$} \\
\cline { 2 - 4 } & 10 blows & 30 blows & 65 blows \\
\hline $100 \%$ of E.S. & 10.89 & 9.21 & 6.78 \\
\hline $5 \%$ Fino $+95 \%$ of E.S & 9.08 & 7.73 & 5.98 \\
\hline $10 \%$ Fino $+90 \%$ of E.S & 7.98 & 6.13 & 5.06 \\
\hline $15 \%$ Fino $+85 \%$ of E.S & 7.09 & 4.99 & 4.11 \\
\hline $20 \%$ Fino $+80 \%$ of E.S & 6.13 & 4.07 & 3.22 \\
\hline $25 \%$ Fino $+75 \%$ of E.S & 5.15 & 3.85 & 2.08 \\
\hline $30 \%$ Fino $+70 \%$ of E.S & 3.97 & 2.16 & 1.18 \\
\hline
\end{tabular}


Table 5 Effect of 'Fino' on California Bearing Ratio (CBR) of the Soil

\begin{tabular}{|c|c|c|c|c|c|c|c|}
\hline \multirow{2}{*}{$\begin{array}{l}\text { Sample } \\
\text { Proportions }\end{array}$} & \multicolumn{6}{|c|}{$\begin{array}{l}96 \text { hours Soaked, Three-Point CBR Value } \\
\text { (AASHTO T-193) }\end{array}$} & \multirow{2}{*}{$\begin{array}{l}\text { ERA } \\
\mathbf{( 2 0 1 3} \\
\mathbf{J} \\
\text { Sub } \\
\text { Grade } \\
\text { Class }\end{array}$} \\
\hline & $\begin{array}{l}\text { No of } \\
\text { Blows }\end{array}$ & $\begin{array}{l}\text { CBR Value } \\
\text { At } 2.54 \mathrm{~mm} \\
(\%)\end{array}$ & $\begin{array}{l}\text { Dry } \\
\text { Density } \\
\mathrm{g} / \mathrm{cm} 3\end{array}$ & $\begin{array}{l}\text { CBR } \\
\text { Swell } \\
(\%)\end{array}$ & $\begin{array}{l}95 \% \\
\text { MDD } \\
\mathrm{g} / \mathrm{cm} 3\end{array}$ & $\begin{array}{l}\text { CBR Value } \\
\text { at } 95 \% \text { of } \\
\text { MDD } \\
(\%)\end{array}$ & \\
\hline \multirow{3}{*}{$\begin{array}{l}5 \% \text { Fino }+95 \% \\
\text { Clay }\end{array}$} & 10 & 1.05 & 1.015 & 9.08 & \multirow{3}{*}{1.21} & \multirow{3}{*}{1.82} & \multirow{3}{*}{ S1 } \\
\hline & 30 & 1.65 & 1.165 & 7.73 & & & \\
\hline & 65 & 2.48 & 1.380 & 5.98 & & & \\
\hline \multirow{3}{*}{$\begin{array}{l}10 \% \text { Fino }+90 \% \\
\text { Clay }\end{array}$} & 10 & 1.11 & 1.065 & 7.98 & \multirow{3}{*}{1.25} & \multirow{3}{*}{2.04} & \multirow{3}{*}{ S1 } \\
\hline & 30 & 1.80 & 1.195 & 6.13 & & & \\
\hline & 65 & 2.62 & 1.395 & 5.06 & & & \\
\hline \multirow{3}{*}{$\begin{array}{l}15 \% \text { Fino }+85 \% \\
\text { Clay }\end{array}$} & 10 & 1.60 & 1.110 & 7.09 & \multirow{3}{*}{1.27} & \multirow{3}{*}{2.58} & \multirow{3}{*}{ S1 } \\
\hline & 30 & 2.34 & 1.240 & 4.99 & & & \\
\hline & 65 & 3.65 & 1.430 & 4.11 & & & \\
\hline \multirow{3}{*}{$\begin{array}{l}20 \% \text { Fino }+80 \% \\
\text { Clay }\end{array}$} & 10 & 2.18 & 1.165 & 6.13 & \multirow{3}{*}{1.31} & \multirow{3}{*}{3.06} & \multirow{3}{*}{ S2 } \\
\hline & 30 & 2.94 & 1.297 & 4.07 & & & \\
\hline & 65 & 4.27 & 1.495 & 3.22 & & & \\
\hline \multirow{3}{*}{$\begin{array}{l}25 \% \text { Fino }+75 \% \\
\text { Clay }\end{array}$} & 10 & 3.18 & 1.178 & 5.15 & \multirow{3}{*}{1.35} & \multirow{3}{*}{4.76} & \multirow{3}{*}{ S2 } \\
\hline & 30 & 4.48 & 1.325 & 3.85 & & & \\
\hline & 65 & 6.45 & 1.520 & 2.08 & & & \\
\hline \multirow{3}{*}{$\begin{array}{l}30 \% \text { Fino }+70 \% \\
\text { Clay }\end{array}$} & 10 & 4.03 & 1.230 & 3.97 & \multirow{3}{*}{1.39} & \multirow{3}{*}{5.94} & \multirow[b]{3}{*}{ S3 } \\
\hline & 30 & 5.50 & 1.350 & 2.16 & & & \\
\hline & 65 & 7.88 & 1.550 & 1.18 & & & \\
\hline
\end{tabular}

This research work observed that the natural soil sample of CBR value is $1.06 \%$. Thus, the natural subgrade soil is classified as S1 of subgrade class as per several specification requirements. It is unsuitable to be used as subgrade material. Therefore, either replacement selective Material Method or the proposed 30\% of 'Fino' stabilizer Method is recommended. Road construction costs include the initial investment and rehabilitation costs that typically entail roads' reinstatement to the original design standards and periodic maintenance costs that involve repairing minor surface defects [12]. To evaluate the cost of the replacement selective Material Method of construction and the proposed $30 \%$ of 'Fino' stabilizer Method, we assumed that the life of a road constructed using either Method would be 10 years. The estimated capital and maintenance costs were calculated for both the replacement selective Material Method and the proposed 30\% of the 'Fino' stabilizer Method (Table 6). The present Worth of cost was calculated using the uniform series present worth equation. The rate of return was estimated as $12 \%$ [12]. In this study, it was assumed that over the 10 year design lifetime, the annual maintenance cost for replacement selective Material Method and the proposed $30 \%$ of 'Fino' stabilizer Method would be at $6 \%$ of the capital costs.

$$
P V=\sum_{n=1}^{n} \frac{c}{(1+i)^{n}}=C\left[\frac{1-(1+i)^{-n}}{i}\right]
$$


Table 6 Cost comparison between Replacement Selective Material Method and The Proposed 30\% Of 'Fino' Stabilizer Method and potential savings that could be realized from the use of 'Fino' in road construction.

\begin{tabular}{|l|l|l|l|l|}
\hline $\begin{array}{l}\text { Total length of } \\
\text { road (Km) }\end{array}$ & $\begin{array}{l}\text { Construction Cost using } \\
\text { Replacement Selective } \\
\text { Material Method(ETB) }\end{array}$ & $\begin{array}{l}\text { 30\% Of 'Fino' } \\
\text { Stabilizer (ETB) }\end{array}$ & Savings (ETB) & $\begin{array}{l}\text { \% } \\
\text { saving }\end{array}$ \\
\hline 1.0 & $19,032,700.00$ & $16,011,915.00$ & $3,020,785.00$ & $16 \%$ \\
\hline
\end{tabular}

Table 7 Cost comparison on subgrade construction using replacement selective Material Method and the proposed $30 \%$ of 'Fino' stabilizer Method (ETB/km).

\begin{tabular}{|l|l|l|l|l|}
\hline $\begin{array}{l}\text { Length of the } \\
\text { road (km) }\end{array}$ & $\begin{array}{l}\text { Subgrade construction cost } \\
\text { using replacement selective } \\
\text { Material Method (ETB) }\end{array}$ & $\begin{array}{l}\text { Subgrade construction costs } \\
\text { using the proposed 30\% of } \\
\text { 'Fino' stabilizer Method (ETB) }\end{array}$ & Savings (ETB) & $\begin{array}{l}\text { Savings } \\
\text { (\%) }\end{array}$ \\
\hline 1.0 & $5,184,000.00$ & $2,928,000.00$ & $2,256,000.00$ & $44 \%$ \\
\hline
\end{tabular}

The thickness of different road pavement layers is determined based on the subgrade class and the traffic class. Depending on CBR values, road subgrades are classified into six classes (S1 to S6) [13]. Assume that the traffic class of the route is T4. Chart A2 of the ERA Flexible Pavement Design Manual is considered for pavement thickness determination. This research observed that the natural soil sample of CBR value is $1.06 \%$, it is found to be in S1 subgrade class while the $30 \%$ of 'Fino' blended sample soil soaked CBR is recorded $5.94 \%$. It is found to be in the S3 subgrade class.

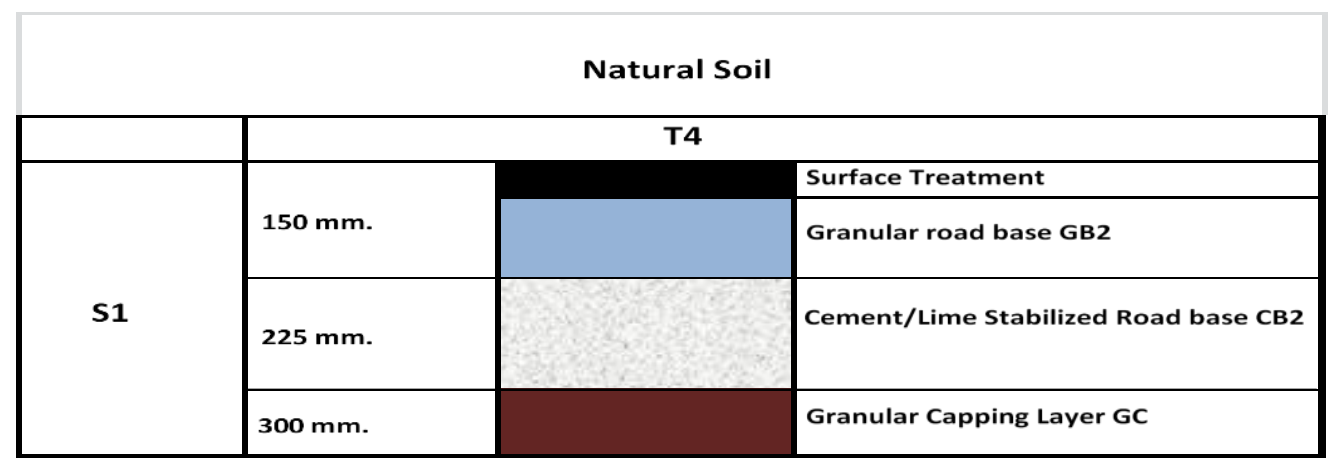

Figure 2 Pavement thickness determination for natural soil

\begin{tabular}{|c|c|c|}
\hline \multicolumn{3}{|c|}{$30 \%$ of 'Fino' blended Soil } \\
\hline & & \\
\hline \multirow{4}{*}{ S3 } & & Surface Treatment \\
\hline & $150 \mathrm{~mm}$. & Granular road base GB2 \\
\hline & $175 \mathrm{~mm}$. & Stabilized Road base CB2 \\
\hline & $150 \mathrm{~mm}$. & Granular Capping Layer GC \\
\hline
\end{tabular}

Figure 3 Pavement Thickness determination for 30\% 'Fino' blended soil 
From the above figure, it can be noted that, by applying soaked CBR on the $30 \%$ of 'Fino' blended subgrade soil, the pavement thickness reduced by $29.6 \%$. The percentage decreases in pavement thickness from natural soil to $30 \%$ of 'Fino' blended soil in the Soaked condition is summarized (Table 8).

Table 8 Effect of soaked CBR on Pavement thickness

\begin{tabular}{|l|l|l|}
\hline \multirow{2}{*}{ Specimen } & $\begin{array}{l}\text { Pavement Thickness } \\
\text { (mm) }\end{array}$ & $\begin{array}{l}\text { \% decrease in } \\
\text { pavement thickness }\end{array}$ \\
\cline { 2 - 2 } & Soaked & $29.6 \%$ \\
\hline Natural Soil & 675 & \\
\hline $30 \%$ 'Fino' By weight & 475 & \\
\hline
\end{tabular}

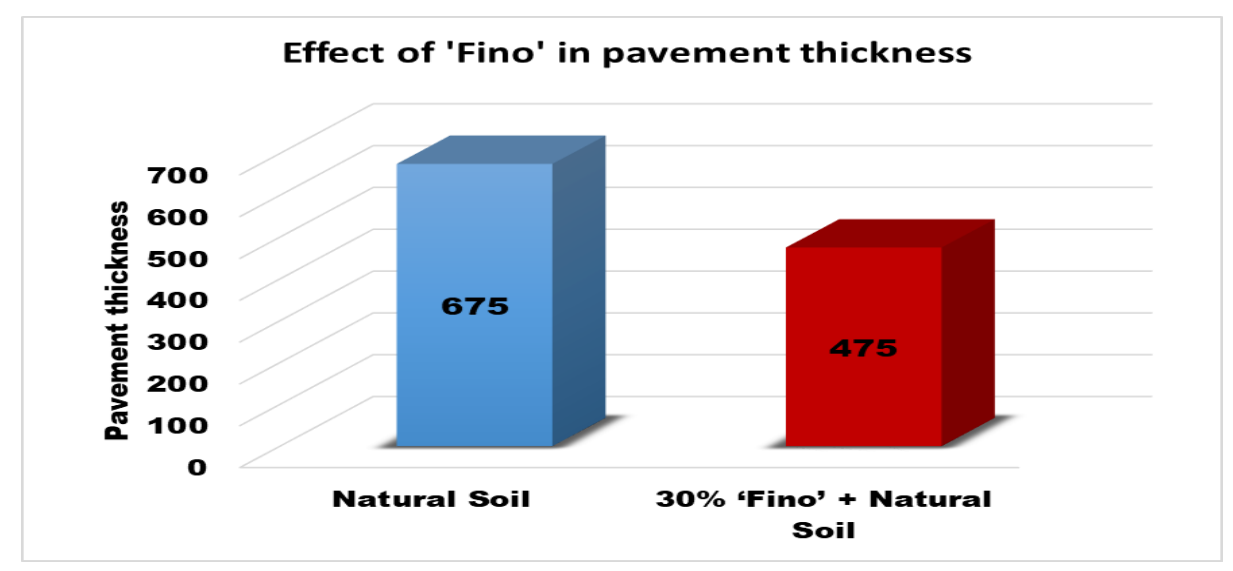

Figure 5 Pavement Thickness natural soil Vs. 30\% 'Fino' Blended Sample

\section{Conclusion}

From laboratory test results, it has been observed that with an increasing percentage of 'Fino,' the expansive subgrade soil has shown improvement in engineering properties. It is significant to meet the specification requirements of several pavement design manuals. Considering the results of soaked CBR tests on the natural subgrade soil at 30\% of 'Fino' blended, the expansive soil's engineering properties were improved. As per several standard requirements, a material to be used as road subgrade should have a liquid limit (LL) less than 60\%, plasticity index (PI) less than $30 \%$, soaked CBR greater than 5\%, and a potential swell less than $2 \%$. Based on this study's result, the treated expansive soil at 30\% of 'Fino' (LL=29.4\%, PI=17.82\%, CBR=5.94\%, and swell 1.18) fulfilled the standard requirements of ERA [13] and AASHTO [14]. The Degree of expansion of the natural subgrade soil has reduced from "Very High to Medium" by applying $30 \%$ by weight of 'Fino.'

\section{Compliance with ethical standards}

\section{Acknowledgments}

Special thanks go to Abraham Woldemichael (Ph.D.) and the Ethiopian Roads Authority (ERA).

\section{Disclosure of conflict of interest}

The author, whose name appears in this article, has hereby agreed that there is no conflict of interest with any organization. 


\section{References}

[1] Atahu MK, Saathoff F, Gebissa A. Engineering Properties of Black Cotton Soil Stabilized with Coffee Husk Ash and Lime. Global Journal of Engineering Science and Research Management. 2020; 7(1): 20-38; Doi: 10.5281/Zenodo.3625617.

[2] Mesfun RT, Quezon ET, Geremew A. Experimental Study of Stabilized Expansive Soil using Pumice Mixed with Lime for Subgrade Road Construction. International Journal of Research - Granthaalayah. 2019; 7(7), 118-124; Doi: $10.5281 /$ zenodo.3355594.

[3] Mamuye Y, Quezon ET, Geremew A. Combined Effects of Molasses-Lime Treatment on Poor Quality Natural Gravel Materials Used for Sub-Base and Base Course Construction. GSJ. 2018; 6(7): 621-633.

[4] Rekha LA, Keerthana B, Ameerlal H. Performance of fly ash stabilized clay reinforced with human hair fiber. Geomechanics and Engineering. 2016; 10(5): 677-687.

[5] Agarwal A, Muley P, Jain PK. An experimental and analytical study on california bearing ratio of lime stabilized black cotton soil. Electronic Journal of Geotechnical Engineering. 2016; 21(20): 6583-6599.

[6] Chala G, Quezon ET, Mekonnen E, Ararsa W. Effects on Modified Properties of Expansive Clay Soil using Waste Hollow Concrete Block (HCB) and Cement Plaster Waste Materials for Subgrade Construction. International Journal of Research - Granthaalayah. 2020; 8(3): 342-347. Doi: 10.5281/zenodo.3742944.

[7] Teferra A, Leikun M. Soil Mechanics. Addis Ababa: Addis Ababa University; 1999.

[8] Nitshit T. Stabilization of expansive soils using Rice Husk Ash (RHA), MSc. Thesis, A.A.U; 2016.

[9] Meron W. Bagasse ash as a Sub-grade soil Stabilizing Material, MSc. Thesis Addis Ababa University; 2014.

[10] ASTM. Annual book of ASTM standards. American Society for Testing and Materials, Philadelphia; 1989.

[11] Addis Ababa City Roads Authority (AACRA). Soil and Material Manual, Section-4 Soil Survey and Treatment; 2004.

[12] African Development Bank; 2014.

[13] Ethiopian Roads Authority (ERA). Design Manual; 2013.

[14] AASHTO. Guide for Design of Pavement Structures, American Association of State Highways and Transportation Officials, USA; 1993. 